Article

\title{
Aqueous-Phase Brown Carbon Formation from Aromatic Precursors under Sunlight Conditions
}

\author{
Kristijan Vidović * $*$, Ana Kroflič $(\mathbb{D}$, Martin Šala@ and Irena Grgić *(i) \\ Department of Analytical Chemistry, National Institute of Chemistry, Hajdrihova 19, SI-1000 Ljubljana, Slovenia; \\ ana.kroflic@ki.si (A.K.); martin.sala@ki.si (M.Š.) \\ * Correspondence: kristijan.vidovic@ki.si (K.V.); irena.grgic@ki.si (I.G.)
}

Received: 22 November 2019; Accepted: 22 January 2020; Published: 24 January 2020

check for

updates

\begin{abstract}
At present, there are still numerous unresolved questions concerning the mechanisms of light-absorbing organic aerosol (brown carbon, $\mathrm{BrC}$ ) formation in the atmosphere. Moreover, there is growing evidence that chemical processes in the atmospheric aqueous phase can be important. In this work, we investigate the aqueous-phase formation of $\mathrm{BrC}$ from 3-methylcatechol (3MC) under simulated sunlight conditions. The influence of different $\mathrm{HNO}_{2} / \mathrm{NO}_{2}{ }^{-}$concentrations on the kinetics of $3 \mathrm{MC}$ degradation and $\mathrm{BrC}$ formation was investigated. Under illumination, the degradation of $3 \mathrm{MC}$ is faster $\left(\mathrm{k}_{2 \mathrm{nd} \text { (global }}=0.075 \mathrm{M}^{-1} \cdot \mathrm{s}^{-1}\right)$ in comparison to its degradation in the dark under the same solution conditions $\left(\mathrm{k}_{2 \mathrm{nd}}=0.032 \mathrm{M}^{-1} \cdot \mathrm{s}^{-1}\right)$. On the other hand, the yield of the main two products of the dark reaction (3-methyl-5-nitrocatechol, 3M5NC, and 3-methyl-4-nitrocatechol, 3M4NC) is low, suggesting different degradation pathways of $3 \mathrm{MC}$ in the sunlight. Besides the known primary reaction products with distinct absorption at $350 \mathrm{~nm}$, second-generation products responsible for the absorption above $400 \mathrm{~nm}$ (e.g., hydroxy-3-methyl-5-nitrocatechol, 3M5NC-OH, and the oxidative cleavage products of $3 \mathrm{M} 4 \mathrm{NC}$ ) were also confirmed in the reaction mixture. The characteristic mass absorption coefficient (MAC) values were found to increase with the increase of $\mathrm{NO}_{2}{ }^{-} / 3 \mathrm{MC}$ concentration ratio (at the concentration ratio of 50, MAC is greater than $4 \mathrm{~m}^{2} \cdot \mathrm{g}^{-1}$ at $350 \mathrm{~nm}$ ) and decrease with the increasing wavelength, which is characteristic for BrC. Yet, in the dark, roughly $50 \%$ more $\mathrm{BrC}$ is produced at comparable solution conditions (in terms of MAC values). Our findings reveal that the aqueous-phase processing of 3MC in the presence of $\mathrm{HNO}_{2} / \mathrm{NO}_{2}{ }^{-}$, both under the sunlight and in the dark, may significantly contribute to secondary organic aerosol (SOA) light absorption.
\end{abstract}

Keywords: brown carbon chromophores; biomass burning; photooxidation; nitration; nitrophenols; methylnitrocatechols; mass absorption coefficient

\section{Introduction}

The existence of light-absorbing organic aerosols in the atmosphere, also termed as brown carbon $(\mathrm{BrC})$, has become increasingly evident in recent years [1-3]. In contrast to black carbon (BC), which strongly absorbs light in the entire spectral range [4], BrC typically absorbs in the near-UV (300-400 nm) and blue-to-green visible ranges $(400-550 \mathrm{~nm})[1,2,5]$. BrC impacts radiative forcing directly by absorbing solar irradiation and also indirectly by influencing the cloud formation [6,7]. In addition, its components can take part in different (photo)chemical reactions in the atmosphere and can also have harmful effects on the environment and living organisms $[1,8]$.

$\mathrm{BrC}$ is largely observed in areas influenced by biomass and biofuel burning and is often attributed to primary emissions $[1,9]$. However, there is more and more evidence that secondary transformations of primarily emitted volatile organic compounds (VOCs), in the gas and/or in the atmospheric aqueous phase, also contribute to $\mathrm{BrC}$ formation [10-12]. Important precursors to $\mathrm{BrC}$ are aromatic compounds, which contribute significantly to the budget of atmospheric pollution [13]; among those, substituted 
aromatics are especially important [14]. A class of aromatics with strong absorption in the near UV and visible are nitrophenols (NP), which are frequently determined in atmospheric particulate matter (PM), with elevated concentrations in winter PM and being primarily associated with biomass burning (BB) [15-19]. It has recently been shown that several nitroaromatic pollutants, such as NP, nitrocatechols (NC), and methylnitrocatechols (MNC), can be formed via (photo)chemical oxidation of preferentially gas-phase precursors in the atmosphere $[20,21]$. Moreover, evidence exists that their formation can take place in the atmospheric aqueous phase, which additionally contributes to the atmospheric abundance of these compounds [11,22,23].

At present, there are numerous open questions concerning the mechanisms of BrC formation, particularly those in cloud droplets and aqueous particles. However, there is rising evidence that chemical processes in the atmospheric condensed phase can efficiently contribute to organic aerosol aging, and thus eventually also to light-absorbing secondary organic aerosol (SOA) formation [24,25]. Yellow-colored MNC have been recognized as essential constituents of BB SOA and further also proposed as suitable tracer compounds $[15,16,22,26]$. Their complex formation mechanisms under nighttime conditions in the atmospheric aqueous phase have recently been extensively studied [27,28]. Moreover, it has been demonstrated that under sunlight conditions, the formation of nitroguaiacols (nitrated 2-methoxyphenols, NG) and their aging in the atmospheric aqueous phase are even more complex [11,23]. In general, nitrophenols have been shown to be susceptible to direct photolysis and to photo-oxidation [29-31]; as a result, the light-absorbing properties of BrC can change significantly during atmospheric aging [32,33]. Hems and Abbatt [33] have recently investigated the mechanism of color enhancement and fate of nitrophenols (NC, NG, and dinitrophenol) during aqueous-phase photo-oxidation. They have found out that the initially fast-formed nitrophenols, being functionalized with additional $\mathrm{OH}$ groups, likely lead to the increased absorption in the visible range, whereas further reactions lead to product formation with poor or no visible absorption (i.e., in the process called bleaching).

In this work, aqueous-phase transformations of 3-methylcatechol (3MC) as an important precursor to light-absorbing MNC were investigated under atmospheric sunlight conditions. The main goal was to find out how photochemical processing affects the kinetics of 3MC degradation at different $\mathrm{HNO}_{2} / \mathrm{NO}_{2}{ }^{-}$concentrations, and how the absorptive properties of the reaction mixture change during the aging. Although $\mathrm{NO}_{3}{ }^{-}$is the prevailing nitrogen species in atmospheric aerosols, $\mathrm{HNO}_{2} / \mathrm{NO}_{2}{ }^{-}$is known for its much higher reactivity at ambient conditions, at least in the dark, and is thus considered important for SOA formation and aging. Special attention was paid to the main dark BrC products, 3-methyl-5-nitrocatechol (3M5NC), and 3-methyl-4-nitrocatechol (3M4NC), and to the possible formation of absorbing second-generation products, such as hydroxy-3-methyl-5-nitrocatechol (3M5NC-OH). In addition, the influence of different reaction conditions on $\mathrm{BrC}$ formation/decomposition was quantified by a cumulative parameter, mass absorption coefficient (MAC in $\mathrm{m}^{2} \mathrm{~g}^{-1}$ ), which was used to describe the evolution of $\mathrm{BrC}$ during the solution aging.

\section{Materials and Methods}

\subsection{Materials}

3-methylcatechol $(3 \mathrm{MC})$ (purity $\geq 98 \%$ ) and sodium nitrite $\left(\mathrm{NaNO}_{2}, \mathrm{ACS}\right.$ reagent, $\left.\geq 97.0 \%\right)$, both from Sigma-Aldrich were used for the reaction mixture preparation in high purity water $(18.2 \mathrm{M} \Omega \mathrm{cm})$, supplied by a Milli-Q water purification system. Standards of two reaction products, 3M5NC and 3M4NC, were prepared in the laboratory by the procedures adopted from Palumbo [34] and Kitanovski [35]. Sulfuric acid $98 \%\left(\mathrm{H}_{2} \mathrm{SO}_{4}\right.$, EMSURE, p.a. grade) was used for the $\mathrm{pH}$ adjustment.

For the quantification of $3 \mathrm{MC}, \mathrm{NaNO}_{2}$ and first-generation reaction products (3M5NC and $3 \mathrm{M} 4 \mathrm{NC}$ ), acetonitrile (Sigma-Aldrich, St. Louis, MO, USA, gradient grade, for HPLC >99.9\%) and formic acid (Kemika, Zagreb, Croatia) were used for mobile phase preparation. For the second-generation product 
identification, methanol (Fluka, Chromosolv LC-MS grade, $\geq 99.9 \%$ ) and an ion-pair reagent for LC-MS Dibutylammonium Acetate-DBAA (Tokyo Chemical Industry, Tokyo, Japan, $0.5 \mathrm{~mol} \cdot \mathrm{L}^{-1}$ ) were used.

\subsection{Laboratory Experiments}

The photolysis of $3 \mathrm{MC}$ in mildly acidic $\left(\mathrm{pH}=4-5\right.$, adjusted with $\left.\mathrm{H}_{2} \mathrm{SO}_{4}\right)$ aqueous solutions of sodium nitrite $\left(\mathrm{NaNO}_{2} ;\right)$ was investigated at ambient temperature $\left(25^{\circ} \mathrm{C}\right)$. The reactions were carried out in a custom-built reactor, which is a modified rotating evaporator (Büchi, Flawil, Switzerland) equipped with a thermostated bath [36]. Only briefly, a low-volume condenser was installed to prevent significant evaporation from the solution ensuring a closed physical system. The reaction mixture $(100 \mathrm{~mL})$ was continuously mixed by rotation $(50 \mathrm{rpm})$ of a round-bottom flask made of the DURAN glass (transparent one for daytime experiments and amber glass for dark reactions). For illumination, a LOT-QuantumDesign Europe solar simulator (L.O.T.-Oriel GmbH \& Co. KG, Darmstadt, Germany) equipped with a xenon short-arc lamp ( $300 \mathrm{~W}$, ozone free) was used. According to the specifications, the simulator produces irradiation equivalent to approximately one sun at the working distance of $180 \mathrm{~mm}$. Moreover, the cut-off of the DURAN glass at $300 \mathrm{~nm}$ resembles the absorption of the stratospheric ozone, which allows us to mimic ambient conditions very well. The concentrations of $3 \mathrm{MC}$ and $\mathrm{H}_{2} \mathrm{SO}_{4}$ were fixed at 0.1 and $0.05 \mathrm{mM}$, respectively. The influence of $\mathrm{NaNO}_{2}$ concentration was investigated at $0.1,0.5,1.0,2.0$, and $5.0 \mathrm{mM}$. Samples (1.5 mL aliquots) were taken from the reaction mixture according to the predefined time protocol (usually each hour). In addition, a control experiment of the direct photolysis of $3 \mathrm{MC}$ without the addition of $\mathrm{NaNO}_{2} / \mathrm{H}_{2} \mathrm{SO}_{4}$, and the dark nitration of $3 \mathrm{MC}$ in acidic $\mathrm{NaNO}_{2}(1$ and $2 \mathrm{mM})$ solutions were performed.

An ultra-high pressure liquid chromatography (UltiMate 3000 UHPLC System; Thermo Fischer Scientific, Waltham, MA, USA) coupled with a diode array detector (DAD) or a triple quadrupole/linear ion trap mass spectrometer (4000 Q TRAP LC-MS/MS System; Applied Biosystems/MDS Sciex) was used for the detection of reactants and products. For the quantification of $3 \mathrm{MC}, \mathrm{NaNO}_{2}$, and first-generation products (3M5NC and 3M4NC), an isocratic elution program with acetonitrile/0.1\% formic acid (70/30, $V / V)$ at the flow rate of $0.6 \mathrm{~mL} \cdot \mathrm{min}^{-1}$ was applied, assuring the separation of components on an Atlantis T3 column $\left(3.0 \times 150 \mathrm{~mm}^{2}, 3 \mu \mathrm{m}\right.$ particle size; Waters, Milford, MA, USA). The injection volume and the column temperature were $10 \mu \mathrm{L}$ and $30^{\circ} \mathrm{C}$. The detection wavelengths used in the case of HPLC-DAD measurements were $275 \mathrm{~nm}$ for $3 \mathrm{MC}, 345 \mathrm{~nm}$ for MNC, and $355 \mathrm{~nm}$ for $\mathrm{NaNO}_{2}$. For the second-generation product identification $(\mathrm{m} / \mathrm{z} 182$ and 184), different chromatographic conditions were used: a Hypersil GOLD aQ column $\left(2.1 \times 150 \mathrm{~mm}^{2}, 3 \mu \mathrm{m}\right.$ particle size; Thermo Scientific, Waltham, MA, USA) and an isocratic elution with methanol/50 mM DBAA $(10 / 90, V / V)$ at the flow rate of $0.3 \mathrm{~mL} \cdot \mathrm{min}^{-1}$. The injection volume and the column temperature were again $10 \mu \mathrm{L}$ and $30^{\circ} \mathrm{C}$. The detection wavelength used in this case was $388 \mathrm{~nm}$.

Absorption spectra of the reaction solution were measured offline in a $1 \mathrm{~cm}$ quartz cuvette with a UV-Vis spectrometer (Lambda 25, PerkinElmer, Waltham, MA, USA) immediately after sampling. The absorbance was monitored in a broad spectral range from 200 to $700 \mathrm{~nm}$.

\subsection{Kinetic Analysis}

The experimentally obtained 3MC photolysis profiles were first treated by a pseudo-first-order kinetics:

$$
\frac{\partial c}{\partial t}=-k_{\mathrm{app}} \cdot c
$$

where $c$ is the concentration of $3 \mathrm{MC}, t$ denotes time, and $k_{\text {app }}$ is the apparent pseudo-first-order kinetic rate constant (in $\mathrm{s}^{-1}$ ) of $3 \mathrm{MC}$ degradation. The integrated form of Equation (1a) was fitted to the experimental data points, $c_{0}$ being the initial concentration of $3 \mathrm{MC}$ in the reaction mixture.

$$
c=c_{0} \cdot e^{-k_{\text {app }} \cdot t}
$$


Referring to the direct photolysis of $3 \mathrm{MC}$, which is negligible (see the control experiment), we postulated that the degradation of $3 \mathrm{MC}$ be dependent on the concentration of $\mathrm{NaNO}_{2}$.

$$
\frac{\partial c}{\partial t}=-k_{2 \mathrm{nd}} \cdot c\left(\mathrm{NaNO}_{2}\right) \cdot c
$$

Except for the condition where the initial concentrations of $3 \mathrm{MC}$ and $\mathrm{NaNO}_{2}$ were equal (i.e., $0.1 \mathrm{mM}$; experiment 1), we further assumed constant $\mathrm{NaNO}_{2}$ concentration in the reaction mixture throughout the course of experiment. Second-order kinetic rate constants $\left(k_{2 n d}\right.$ in $\left.\mathrm{M}^{-1} \cdot \mathrm{s}^{-1}\right)$ were thus estimated from $k_{\text {app }}$ as:

$$
k_{\text {app }}=k_{2 \text { nd }} \cdot c\left(\mathrm{NaNO}_{2}\right)_{0} .
$$

$c\left(\mathrm{NaNO}_{2}\right)_{0}$ being the initial concentration of $\mathrm{NaNO}_{2}$ in the reaction mixture. Note, however, that one cannot assume constant $\mathrm{NaNO}_{2}$ concentration during experiment 1 . Therefore, a second-order kinetic treatment was applied in this case, taking into account the measured $c\left(\mathrm{NaNO}_{2}\right)$ at each time of the experiment.

$$
\frac{\partial c}{\partial t}=-k_{2 n d} \cdot c\left(\mathrm{NaNO}_{2}\right)_{t} \cdot c,
$$

where $c\left(\mathrm{NaNO}_{2}\right)_{\mathrm{t}}$ represents the concentration of $\mathrm{NaNO}_{2}$ at the reaction time $t$.

The experimental data for which the assumption of a pseudo-first-order is valid $\left(c\left(\mathrm{NaNO}_{2}\right)=0.5\right.$, 1.0, 2.0, and $5.0 \mathrm{mM}$ ) were further treated simultaneously by the following function:

$$
\frac{\partial c}{\partial t}=-k_{2 \text { nd }}(\text { global }) \cdot c\left(\mathrm{NaNO}_{2}\right)_{0} \cdot c
$$

This gave us a global second-order kinetic rate constant, $k_{2 \text { nd }}$ (global) representing all treated experimental conditions. Note that parameters obtained by accounting for the data at different experimental conditions at once tend to be more universally applied.

OriginPro 2018 was used for the fitting of the model functions to the experimental data (i.e., measured concentration and absorption profiles).

\subsection{Determination of Absorption Properties}

The obtained $k_{2 n d}($ global) (Equation (4)) was further used to quantitatively describe the influence of the studied reaction conditions on $\mathrm{BrC}$ formation. In the case of experiment 1 (Table 1$), k_{2 \text { nd }}$ (global) is not valid; therefore, $k_{\text {app }}$ (Equation (1a)) was used instead. According to the Beer-Lambert Law, the measured absorbance of a sample at a distinct wavelength, $A_{\text {tot }}$ is dependent on the characteristic mass absorption coefficient of contained species $i$ at this wavelength, $\mathrm{MAC}_{i}$, and their concentrations, $c_{i} ; l$ is the absorption path length characteristic of the used cuvette.

$$
A_{\mathrm{tot}}=\sum_{i} \mathrm{MAC}_{i} \cdot c_{i} \cdot l
$$

Table 1. Ratios and yields of quantified 3-methyl-5-nitrocatchol (3M5NC) and 3-methyl-4-nitrocatechol (3M4NC) at different $\mathrm{NaNO}_{2}$ concentrations under sunlight conditions after $8 \mathrm{~h}$ of reaction.

\begin{tabular}{cccccc}
\hline Experiment & 3MC $[\mathbf{m M}]$ & $\mathbf{N a N O}_{\mathbf{2}}[\mathbf{m M}]$ & 3M5NC/3M4NC & $\mathbf{p H}$ & $\begin{array}{c}\text { MNC Product } \\
\text { Yield after 8 h }\end{array}$ \\
\hline 1 & 0.1 & 0.1 & 5 & 3.9 & 0.17 \\
2 & 0.1 & 0.5 & 6 & 4.5 & 0.45 \\
3 & 0.1 & 1.0 & 96 & 4.6 & 0.40 \\
4 & 0.1 & 2.0 & 98 & 4.9 & 0.36 \\
5 & 0.1 & 5.0 & 63 & 5 & 0.27 \\
\hline
\end{tabular}


By definition, $\mathrm{BrC}$ absorbs in the near-UV and visible ranges, so we attributed $A_{\text {tot }}$ measured above $300 \mathrm{~nm}$ to the $\mathrm{BrC}$ formation (note that $3 \mathrm{MC}$ does not absorb in this range). Equation (5a) can be thus expressed as:

$$
A_{\text {tot }}(>300 \mathrm{~nm})=\mathrm{MAC}_{\mathrm{BrC}} \cdot m_{\mathrm{BrC}} \cdot l .
$$

$\mathrm{MAC}_{\mathrm{BrC}}$ (in $\mathrm{m}^{2} \cdot \mathrm{g}^{-1}$ ) being the mass absorption coefficient characteristic of the formed $\mathrm{BrC}$ and

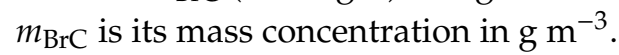

By combining Equation (5b) with the expression for the pseudo-first-order product formation and taking into account the law of conservation of mass (i.e., assuming that all consumed 3MC was converted to $\mathrm{BrC} ; m_{0}$ is the initial $3 \mathrm{MC}$ mass concentration):

$$
m_{\mathrm{BrC}}=m_{0}\left(1-e^{-k_{2 n d}(\text { global }) \cdot c\left(\mathrm{NaNO}_{2}\right)_{0} \cdot t}\right) .
$$

One can describe the evolution of $A_{\text {tot }}$ with time with the following function:

$$
A_{\text {tot }}=\operatorname{MAC}_{\mathrm{BrC}} \cdot m_{0}\left(1-e^{-k_{2 \text { nd }}(\text { global }) \cdot c\left(\mathrm{NaNO}_{2}\right)_{0} \cdot t}\right) \cdot l \cdot
$$

The derived function was fitted to the experimental data points, and characteristic $\mathrm{MAC}_{\mathrm{BrC}}$ values for the investigated experimental conditions were obtained. Note that in the case of experiment 1 Table 1), $k_{\text {app }}$ was used instead of the product of $k_{2 \text { nd(global })}$ and $c\left(\mathrm{NaNO}_{2}\right)_{0}$.

\section{Results and Discussion}

\subsection{Kinetic Analysis of 3MC Photolysis in Mildly Acidic $\mathrm{NaNO}_{2}$ Solution}

In the dark reaction of $3 \mathrm{MC}$ and $\mathrm{NaNO}_{2}$, two main reaction products have been recently quantified, i.e., $3 \mathrm{M} 5 \mathrm{NC}$ and $3 \mathrm{M} 4 \mathrm{NC}$; they accounted for $70-100 \%$ of the reacted $3 \mathrm{MC}$ at similar reaction conditions as used in this study [27]. In addition, the ratio of 3M5NC to 3M4NC was constant during the dark reaction and dependent only on the concentration of $\mathrm{HNO}_{2}$ [27].

Under sunlight conditions, dark reaction mechanisms also exist; thus, 3M5NC and 3M4NC were expected to be formed in this study as well. The performed experiments under illumination are listed in Table 1 together with the corresponding 3M5NC/3M4NCratios and product yields determined after $8 \mathrm{~h}$ of reaction. The product yield was calculated as the sum of concentrations of target reaction products divided by the concentration of the reacted 3MC.

$$
\text { Product yield }=\frac{\Sigma[M N C]_{8 \mathrm{~h}}}{[3 M C]_{0 \mathrm{~h}}-[3 M C]_{8 \mathrm{~h}}} .
$$

Under the sunlight, the cumulative yield of identified MNC products was only up to about $45 \%$. The ratio (and the yield) of 3M5NC to 3M4NC were additionally found to be dependent on the initial concentration of $\mathrm{NaNO}_{2}$ (Table 1). The low product yield and the variable product ratio suggest the existence of different oxidation pathways of $3 \mathrm{MC}$, and formation and/or degradation pathways of MNC products in comparison to the dark reaction.

During the photolysis of $\mathrm{HNO}_{2}$, diverse reactive species are formed (e.g., $\mathrm{OH}, \mathrm{NO}, \mathrm{NO}_{2}$ ), which are possible sinks of 3MC [37]. In general, $\mathrm{OH}$ radicals react with aromatics with high (near-diffusion controlled) rate constants in the order of $10^{10} \mathrm{~L} \cdot \mathrm{mol}^{-1} \cdot \mathrm{s}^{-1}$ at $298 \mathrm{~K}[38,39]$. The reactivity of aromatics with $\mathrm{NO}_{2}$ is still relatively high (in the order of $10^{8}-10^{9} \mathrm{~L} \mathrm{~mol}^{-1} \cdot \mathrm{s}^{-1}$ ), whereas $\mathrm{NO}$ seems to be too weak to react with aromatic compounds directly [23]. In summary, other degradation pathways of $\mathrm{MNC}$, i.e., initiated by radicals, are very likely under illumination [33].

Under illumination, also the decay of $3 \mathrm{MC}$ was greatly dependent on the applied conditions (Table 2). In general, $k_{\text {app }}$ increased as the $\mathrm{NaNO}_{2}$ concentration increased. Note, however, that in the cases where $\mathrm{NaNO}_{2}$ was in excess, $k_{2 n d}$ slightly decreased with $\mathrm{NaNO}_{2}$ addition. This may be 
due to unaccounted 3MC degradation pathways, independent of (or indirectly dependent on) the $\mathrm{NaNO}_{2}$ concentration.

Table 2. Kinetic rate constants (apparent pseudo-first-order, $k_{\text {app }}$; second-order, $k_{2 \text { nd }}$; and global second-order, $k_{2 \text { nd }}$ (global)) of the photolysis of 3-methylcatechol (3MC) in aqueous solution ( $\mathrm{pH}=4.5-5$, $\mathrm{T}=25^{\circ} \mathrm{C}$ ) at different initial concentrations of $\mathrm{NaNO}_{2}$ under simulated sunlight conditions (YES) and in the dark (NO). The initial concentration of $3 \mathrm{MC}$ was always $0.1 \mathrm{mM}$.

\begin{tabular}{|c|c|c|c|c|c|}
\hline Experiment & $\mathrm{NaNO}_{2}[\mathrm{mM}]$ & Sunlight & $k_{\mathrm{app}}\left(\mathrm{s}^{-1}\right)$ & $k_{2 \mathrm{nd}}\left(\mathrm{M}^{-1} \mathrm{~s}^{-1}\right)$ & $k_{2 \text { nd }}($ global $)\left(\mathrm{M}^{-1} \cdot \mathrm{s}^{-1}\right)$ \\
\hline 1 & 0.1 & YES & $7.88 \times 10^{-6}$ & 0.168 & - \\
\hline 2 & 0.5 & YES & $4.47 \times 10^{-5}$ & 0.089 & \multirow{4}{*}{0.075} \\
\hline 3 & 1.0 & YES & $7.30 \times 10^{-5}$ & 0.073 & \\
\hline 4 & 2.0 & YES & $1.30 \times 10^{-4}$ & 0.065 & \\
\hline 5 & 5.0 & YES & $2.40 \times 10^{-4}$ & 0.048 & \\
\hline 6 & 1.0 & $\mathrm{NO}$ & $4.26 \times 10^{-5}$ & 0.043 & \multirow{2}{*}{0.032} \\
\hline 7 & 2.0 & $\mathrm{NO}$ & $5.03 \times 10^{-5}$ & 0.025 & \\
\hline
\end{tabular}

\subsubsection{Kinetic Analysis at Low $\mathrm{NaNO}_{2}$ Concentrations}

The time-dependent concentrations of $3 \mathrm{MC}(0.1 \mathrm{mM}$ initial concentration) in $0.1 \mathrm{mM} \mathrm{NaNO}$ solution under sunlight conditions are shown in Figure 1. In the investigated time range, $k_{\text {app }}$ $\left(7.88 \times 10^{-6} \mathrm{~s}^{-1}\right)$ describes the behavior of this reaction reasonably well and is comparable with the reaction in the dark $\left(8.33 \times 10^{-6} \mathrm{~s}^{-1}\right)$ [27]. However, the yield of identified MNC under sunlight is barely $17 \%$ after $8 \mathrm{~h}$ (Table 1), pointing to different degradation and/or formation pathways of 3MC and $\mathrm{MNC}$, respectively.

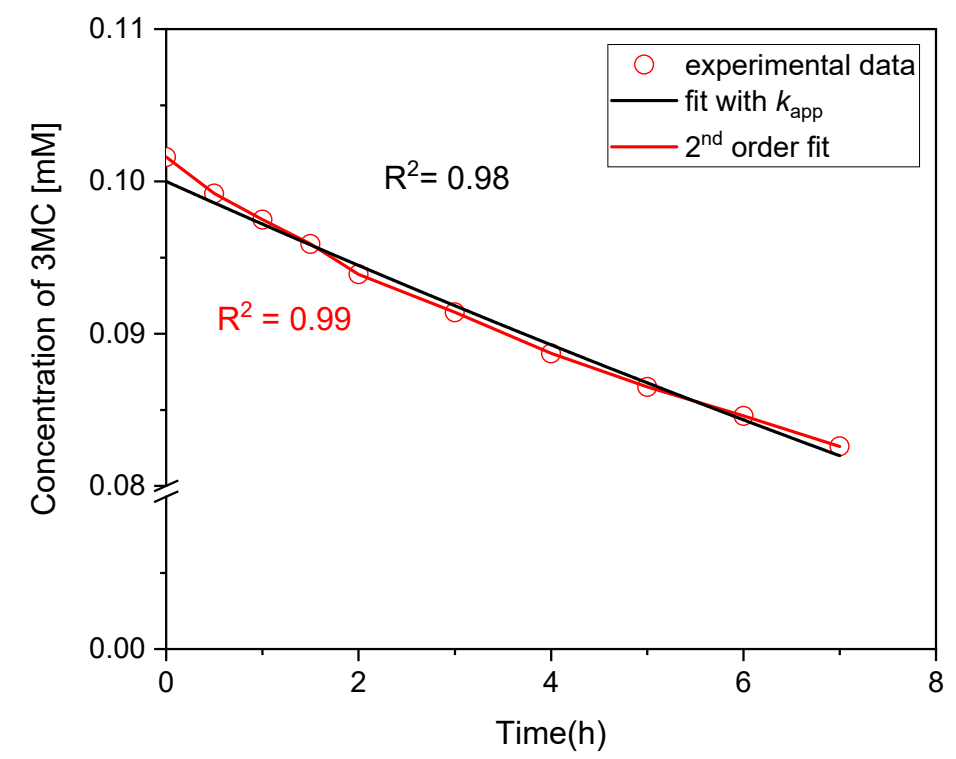

Figure 1. 3-methylcatechol (3MC) degradation in aqueous solution at $0.1 \mathrm{mM}$ initial concentrations of $3 \mathrm{MC}$ and $\mathrm{NaNO}_{2}\left(\mathrm{pH}=3.9, \mathrm{~T}=25^{\circ} \mathrm{C}\right)$. Experimental data (symbols) and calculated time-dependent concentration profiles (lines) for the pseudo-first order $\left(k_{\mathrm{app}}\right)$ and second order $\left(k_{2 \mathrm{nd}}\right)$ kinetics.

Second-order kinetics was also applied to this set of experimental data, and the comparison of both models (Equations (1a) and (3)) is shown in Figure 1. As $k_{\text {app }}$ describes experimental data adequately in the investigated time range, we used it in further calculations with a fair amount of confidence. 


\subsubsection{Kinetic Analysis at High $\mathrm{NaNO}_{2}$ Concentrations}

Time-dependent concentrations of $3 \mathrm{MC}$ in the presence of different initial $\mathrm{NaNO}_{2}$ concentrations (i.e., from 0.5 to $5 \mathrm{mM}$ ) are shown in Figure 2a-d. The lines are the calculated concentration profiles according to the two proposed model functions (Equations (1a) and (4)). By using $k_{\text {app }}$, the experimental data are represented well in all cases; thus, its values were further used to derive $k_{2 \text { nd }}$ according to Equation (2b) for each experiment individually (see Table 2). Yet, a global fit was also performed to get a more reliable second-order rate constant, $k_{2 n d(\text { global })}$, by which the kinetics of $3 \mathrm{MC}$ decay at all treated conditions is still well described (black lines in Figure 2).

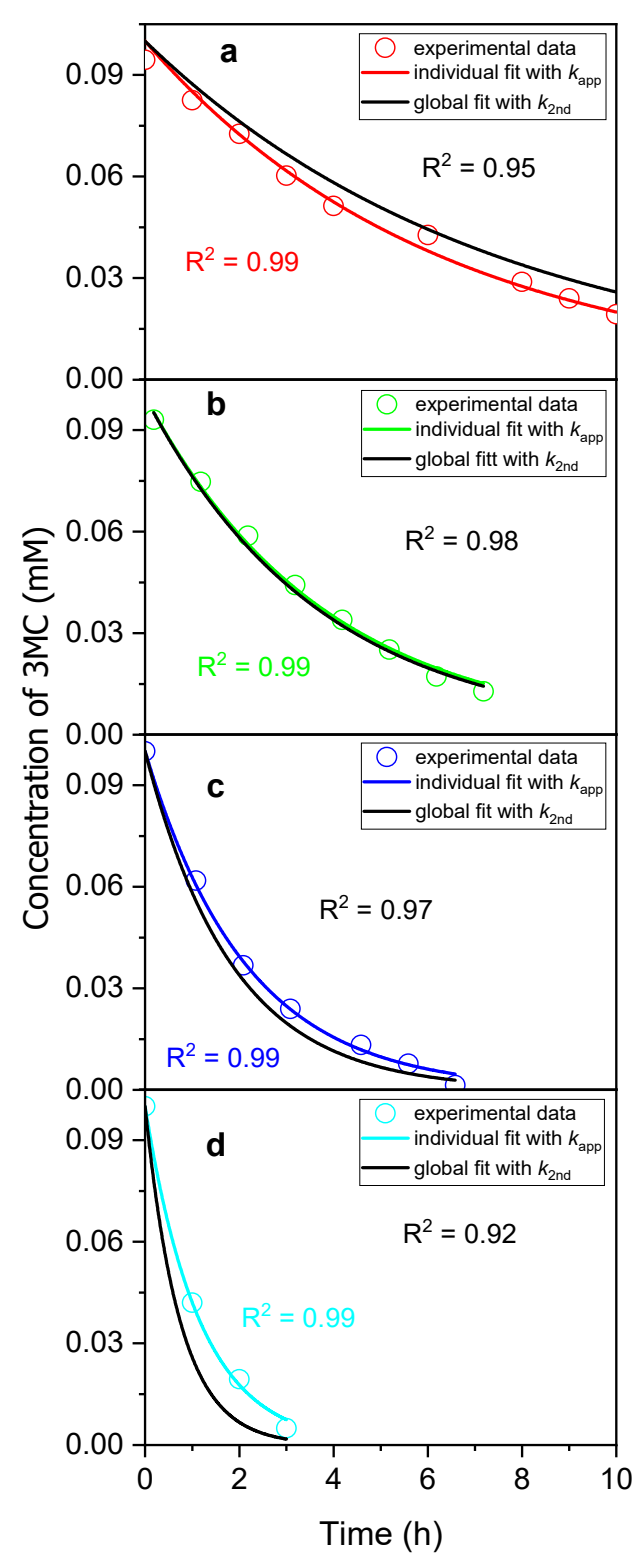

Figure 2. 3-methylcatechol (3MC) degradation in aqueous solution at different initial concentrations of $\mathrm{NaNO}_{2}\left(\mathrm{pH}=4.5-5, \mathrm{~T}=25^{\circ} \mathrm{C}\right)$. The concentrations of $\mathrm{NaNO}_{2}$ were $0.5(\mathbf{a}), 1.0(\mathbf{b}), 2.0(\mathbf{c})$, and $5.0 \mathrm{mM}$ (d). Experimental data (symbols) and calculated time-dependent concentration profiles (lines) for the pseudo-first order $\left(k_{\mathrm{app}}\right)$ and global second order $\left(k_{2 \text { nd }}(\right.$ global $\left.)\right)$ fits.

The rate constant for 3MC decay in the simulated sunlight $\left(k_{2 \text { nd(global })}=0.075 \mathrm{M}^{-1} \cdot \mathrm{s}^{-1}\right)$ is twice as high as in the dark $\left(k_{2 \text { nd }}=0.032 \mathrm{M}^{-1} \cdot \mathrm{s}^{-1}\right)$ under similar initial conditions (Table 2). As mentioned above, several different degradation mechanisms are possible in the sunlight that are prevented in 
the dark. Similarly, under the sunlight, $k_{2 n d}$ for the $3 \mathrm{MC}$ decay at the lowest $\mathrm{NaNO}_{2}$ concentration $(0.1 \mathrm{mM})$ is almost twice as that at higher $\mathrm{NaNO}_{2}$ concentrations $(0.5-5 \mathrm{mM})$. The reason might be in the competition between $\mathrm{NO}_{2}{ }^{-}$and $3 \mathrm{MC}$ for $\mathrm{OH}$ radicals and other reactive species at these experimental conditions. When $\mathrm{HNO}_{2} / \mathrm{NO}_{2}{ }^{-}$is in excess, $\mathrm{OH}$ radicals preferentially react with $\mathrm{NO}_{2}{ }^{-}$, whereas only a minor fraction reacts with $3 \mathrm{MC}$, which results in its slower degradation $[37,39]$.

\subsection{Absorption Spectra and BrC Formation}

\subsubsection{Low $\mathrm{NaNO}_{2}$ Concentrations}

As has recently been reported in our previous study on the nighttime aqueous-phase formation of MNC, the two identified products, i.e., 3M5NC and 3M4NC, strongly absorb in the near UV range, whereas the reaction mixture also exhibited notable absorption in the visible range, which are all characteristic of $\mathrm{BrC}$ [27]. Moreover, in the dark, the enhanced absorption in the visible range can be attributed to MNC degradation by hydroxylation and oxidative cleavage by water addition [28].

Figure 3a-f shows the time evolution of absorption spectra during the aging of 3MC in mildly acidic $\mathrm{NaNO}_{2}$ solutions under illumination. The dependence of absorbance on the initial concentration ratio of $3 \mathrm{MC}$ to $\mathrm{NaNO}_{2}$ was investigated. Compared to the photolysis of $3 \mathrm{MC}$ only (without the addition of $\mathrm{NaNO}_{2}$ ), where we did not observe any change in the absorption spectrum over the reaction time scale (Figure 3a), the spectrum noticeably evolves already at low $\mathrm{NaNO}_{2}$ concentration (i.e., $0.1 \mathrm{mM}$, Figure $3 \mathrm{~b}$ ). The absorption around $350 \mathrm{~nm}$ increases with time and corresponds to the formation of first-generation products, 3M5NC and 3M4NC [27]. Nevertheless, only a slight increase in the absorption is in agreement with the ascertainment that at low $\mathrm{NO}_{\mathrm{x}}, \mathrm{BrC}$ formation by nitration is not preferred $[40,41]$. Note also the low product yield at the lowest $\mathrm{NO}_{2}{ }^{-}$concentration (Table 1).

The time evolution of absorbance at 350, 400, and $410 \mathrm{~nm}$, measured experimentally, and modeled using Equation (7), is presented in Figure 4. The predicted absorption describes the experimental data fairly well; a somewhat weaker correlation can be explained by extensive scattering of data due to unreliable measurements at low absorbance (below 0.2). The developed absorption above $400 \mathrm{~nm}$ at long reaction times may, among others, correspond to hydroxylated and ring cleavage products formed from MNC, the same as in the dark [28]. See further discussion for justification.

\subsubsection{High $\mathrm{NaNO}_{2}$ Concentrations}

At higher $\mathrm{NaNO}_{2} / 3 \mathrm{MC}$ concentration ratios, the absorption at $350 \mathrm{~nm}$ is substantially enhanced in comparison to the experiment with equimolar amounts of both reactants, resulting in the appearance of a distinctive peak with the maximum at this wavelength (Figure $3 c-e$ ). In addition, the absorption above $400 \mathrm{~nm}$ becomes more pronounced. The enhancement in absorption at examined wavelengths is the fastest at the highest $\mathrm{NaNO}_{2}$ concentration (Figure 3f).

As already mentioned before, the two products, 3M5NC and 3M4NC with a pronounced absorption peak at $350 \mathrm{~nm}$ can react further, forming second-generation products, which can be responsible for the development of absorption in the visible region. According to our recent study [28], the secondary products can be $3 \mathrm{M} 5 \mathrm{NC}-\mathrm{OH}$ and the oxidative cleavage products of 3M4NC. Their spectroscopic characteristics (both exhibit the absorption maxima at cca. $400 \mathrm{~nm}$ and the latter another one at around $500 \mathrm{~nm}$ [28]) are in agreement with the presented results and were also confirmed in one of the investigated reaction mixtures by comparison with the recently published data. The chromatogram of the reaction mixture is shown in Figure 5 and mass spectra corresponding to the characteristic peaks were additionally analyzed by an LC-MS/MS experiment. The peak at $2.5 \mathrm{~min}$ showed the $\mathrm{m} / \mathrm{z}$ ratio of 183 corresponding to $3 \mathrm{M} 5 \mathrm{NC}-\mathrm{OH}$, while the peak at $4.5 \mathrm{~min}$ with the $\mathrm{m} / \mathrm{z}$ of 184 corresponds to the oxidative cleavage products of $3 \mathrm{M} 4 \mathrm{NC}$, which additionally confirmed the identity of investigated compounds. 


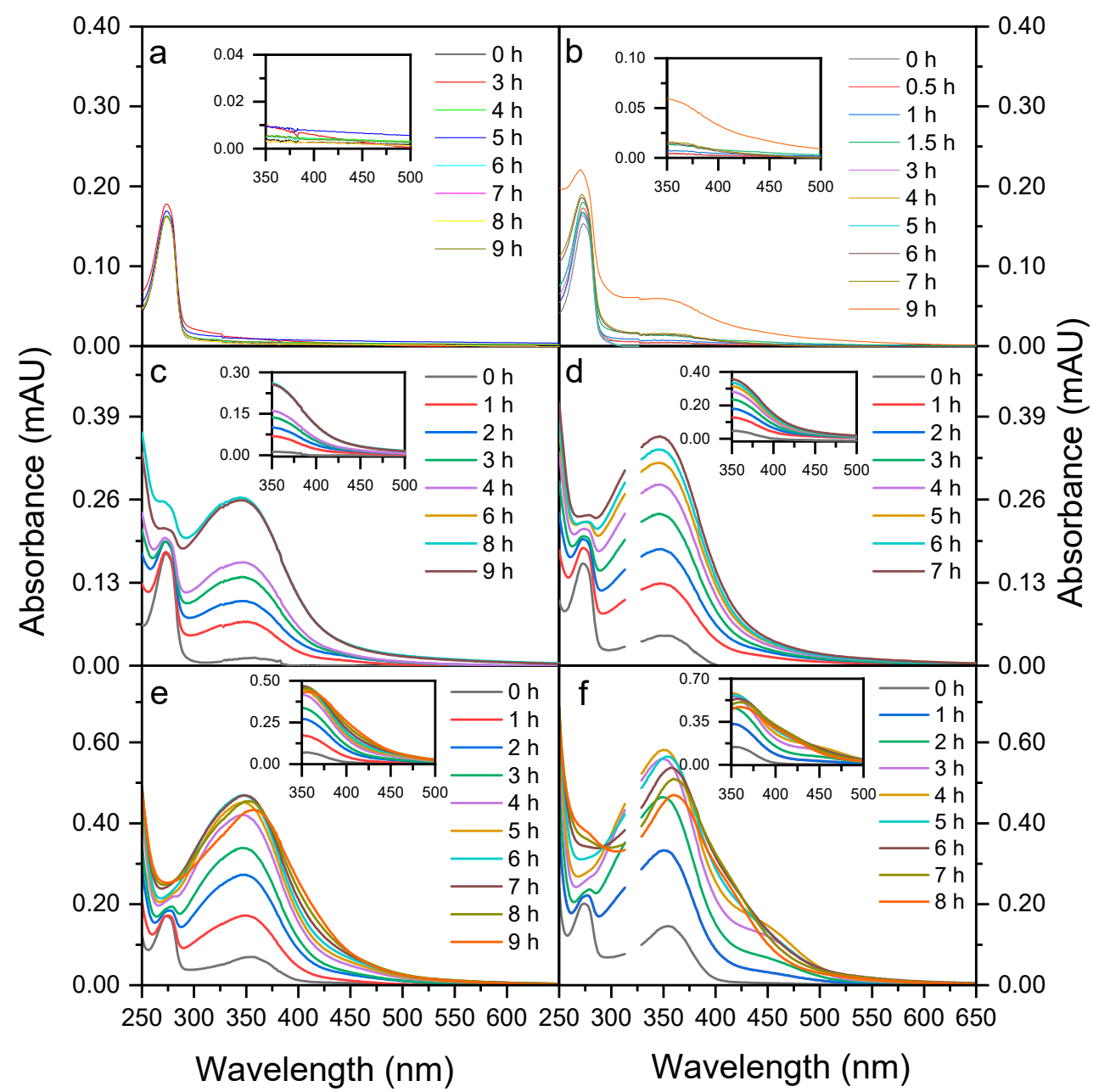

Figure 3. Absorption spectra of the reaction mixture during the photolysis of 3-methylcatechol (3MC) in aqueous $\mathrm{NaNO}_{2}$ solutions $\left(\mathrm{pH}=4-5, \mathrm{~T}=25^{\circ} \mathrm{C}\right.$ ) at different initial concentrations of $\mathrm{NaNO}_{2}$. The concentration of $3 \mathrm{MC}$ was always $0.1 \mathrm{mM}$, while the concentrations of $\mathrm{NaNO}_{2}$ were $0(\mathbf{a}), 0.1$ (b), 0.5 (c), 1 (d), 2 (e), and $5 \mathrm{mM}(\mathbf{f})$. The discontinuation in the absorption spectra $(\mathrm{d}, \mathrm{f})$ is due to the issues with the instrument and does not affect the results in any way.

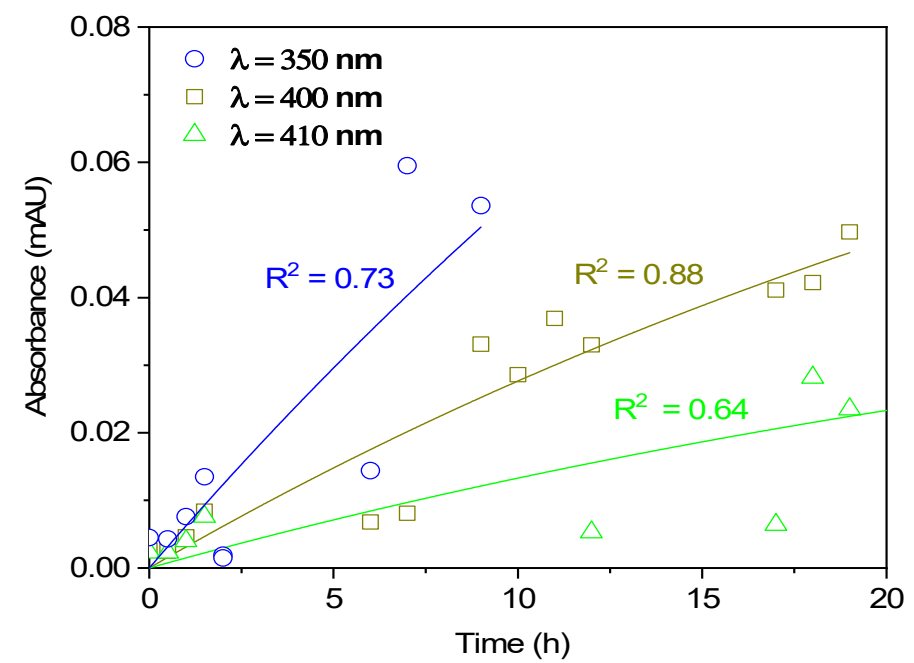

Figure 4. Brown carbon $(\mathrm{BrC})$ formation in $0.1 \mathrm{mM}$ 3-methylcatechol and $0.1 \mathrm{mM} \mathrm{NaNO} \mathrm{m}_{2}$ under sunlight conditions. Experimentally measured (symbols) and modeled absorbance (solid lines) at different wavelengths representative of $\mathrm{BrC}$. 


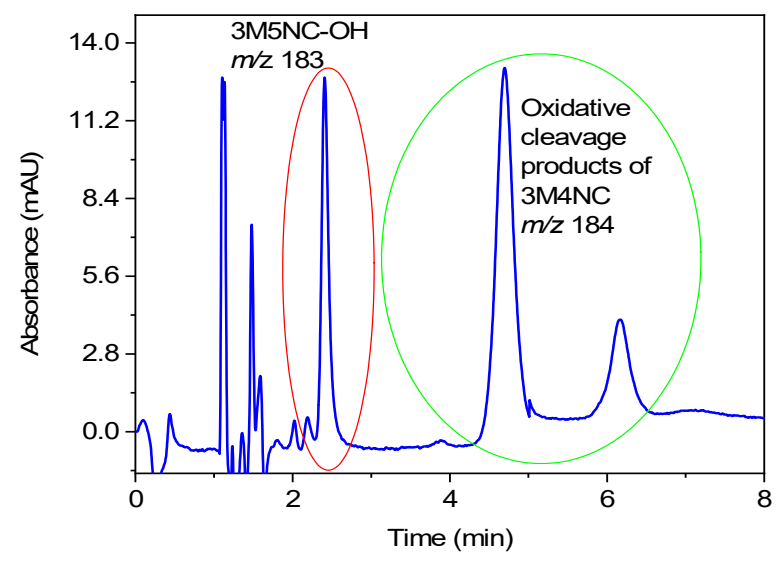

Figure 5. Chromatogram recorded at $388 \mathrm{~nm}$ for the reaction mixture of $0.1 \mathrm{mM} 3 \mathrm{MC}$ and $1 \mathrm{mM}$ $\mathrm{NaNO}_{2}$ under sunlight conditions is comparable to the one from our previous study [28]. The peak at $2.5 \mathrm{~min}$ with the $\mathrm{m} / \mathrm{z}$ ratio of 183 corresponds to $3 \mathrm{MC} 5 \mathrm{NC}-\mathrm{OH}$, while the peak at $4.5 \mathrm{~min}$ with the $\mathrm{m} / \mathrm{z}$ of 184 corresponds to oxidative cleavage products of 3M4NC.

The time evolution of absorbance, experimentally measured and modeled by using Equation (7), is presented in Figure 6 for all remaining four experimental conditions. At the initial concentrations of 0.5 and $1 \mathrm{mM} \mathrm{NaNO}$, the experimental data are very well fitted with the applied absorption model (Figure 6a,b). However, at higher $\mathrm{NaNO}_{2}$ concentrations, the exponential shape of absorbance changes into the sigmoidal one, which is most noticeable at $5 \mathrm{mM} \mathrm{NaNO}_{2}$ in the visible range (Figure $6 \mathrm{c}, \mathrm{d}$ ). This behavior could be attributed to the formation of the second-generation products, which are particularly responsible for the enhanced absorption above $400 \mathrm{~nm}$ (e.g., 3M5NC-OH and the oxidative cleavage products of $3 \mathrm{M} 4 \mathrm{NC}$ ). As the proposed absorption model only considers the one-step transformation of $3 \mathrm{MC}$ into $\mathrm{BrC}$, it fails to precisely reproduce such complex behavior of the experimental system. Furthermore, at the highest $\mathrm{NO}_{2}{ }^{-}$concentration, $3 \mathrm{MC}$ is completely consumed during the experiment; therefore, primary reaction products, 3M5NC and 3M4NC, stopped forming already before the end of the experiment. Consequently, the decay of absorbance is observed in the second part of the experiment, and the predicting ability of the absorption model is even worse in this case because it does not account for any of the explained phenomena.

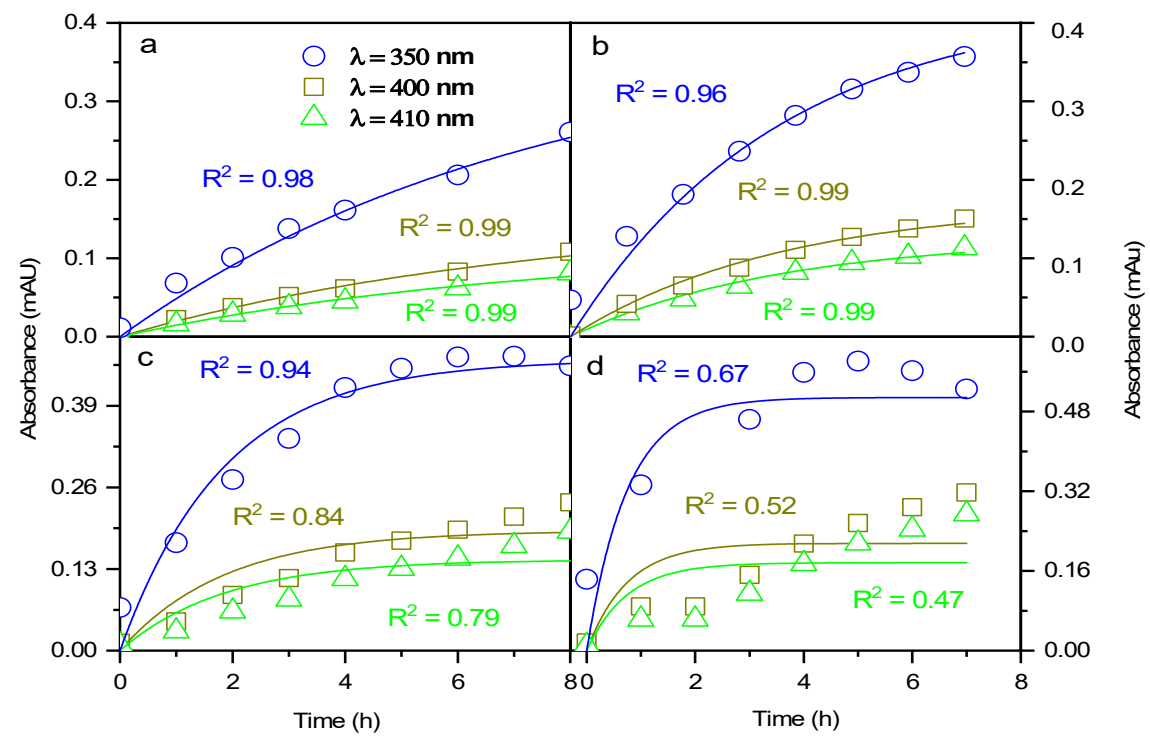

Figure 6. BrC formation in the reaction mixture of $0.1 \mathrm{mM}$ 3-methylcatechol and (a) 0.5, (b) 1, (c) 2, and (d) $5 \mathrm{mM} \mathrm{NaNO}_{2}$ under sunlight conditions. Experimentally measured (symbols) and modelled absorbance (solid lines) at different wavelengths, representative of $\mathrm{BrC}$ are shown. 
In contrast to the illuminated experiments, the model describes the experimental data of dark reactions very well, also at high $\mathrm{NaNO}_{2}$ concentrations ( $0.1 \mathrm{mM} 3 \mathrm{MC}$ and $2 \mathrm{mM} \mathrm{NaNO}$; Figure 7). These results additionally support our discussion that under the sunlight, the formed $\mathrm{BrC}$ species undergo secondary reactions substantially.

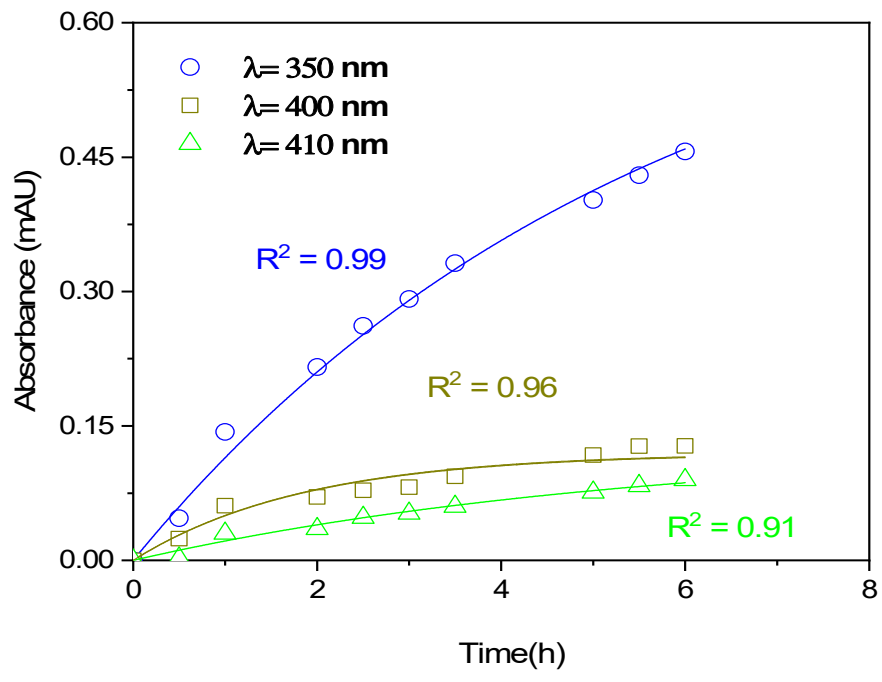

Figure 7. BrC formation in the reaction mixture of $0.1 \mathrm{mM}$ 3-methylcatechol and $2 \mathrm{mM} \mathrm{NaNO}_{2}$ in the dark. Experimentally measured (symbols) and modelled absorbance (solid lines) at different wavelengths, representative of $\mathrm{BrC}$ are shown.

From characteristic MAC values at 350, 400, and $410 \mathrm{~nm}$ listed in Table 3 one can see that with increasing $\mathrm{NaNO}_{2}$ concentration, higher MAC values are obtained corresponding to more $\mathrm{BrC}$ production; i.e., the highest was in the order of $4 \mathrm{~m}^{2} \mathrm{~g}^{-1}$ for $5 \mathrm{mM} \mathrm{NaNO}_{2}$ at $350 \mathrm{~nm}$. It should be emphasized that in the dark (experiments 6 and 7), roughly $50 \%$ more $\mathrm{BrC}$ is produced at comparable solution conditions. This is consistent with the finding that under the sunlight, $\mathrm{BrC}$ degradation, and so the solution bleaching, may proceed via the reactions with $\mathrm{OH}$ radicals leading to products with poor absorption in the visible region [33].

Table 3. Wavelength-dependent mass absorption coefficients $\left(\mathrm{MAC}_{350}, \mathrm{MAC}_{400}\right.$, and $\left.\mathrm{MAC}_{410}\right)$ for $\mathrm{BrC}$ formation during the photolysis of 3-methylcatechol in aqueous $\mathrm{NaNO}_{2}$ solutions ( $\mathrm{pH} 4-5, \mathrm{~T}=25^{\circ} \mathrm{C}$ ) at different initial concentrations of $\mathrm{NaNO}_{2}$ under simulated sunlight (YES) and in the dark (NO). The concentration of $3 \mathrm{MC}$ was always $0.1 \mathrm{mM}$.

\begin{tabular}{cccccc}
\hline Experiment & $\mathbf{N a N O}_{\mathbf{2}}(\mathbf{m M})$ & Sunlight & $\begin{array}{c}\mathbf{M A C}_{\mathbf{B r C}(350 \mathrm{~nm})} \\
\left(\mathbf{m}^{\mathbf{2}} / \mathbf{g}\right)\end{array}$ & $\begin{array}{c}\mathbf{M A C}_{\mathbf{B r C}(400 \mathrm{~nm})} \\
\left(\mathbf{m}^{\mathbf{2}} / \mathbf{g}\right)\end{array}$ & $\begin{array}{c}\mathbf{M A C}_{\mathbf{B r C}(400 \mathrm{~nm})} \\
\left(\mathbf{m}^{\mathbf{2}} \mathbf{g}\right)\end{array}$ \\
\hline 1 & 0.1 & YES & 1.80 & 0.87 & 0.43 \\
2 & 0.5 & YES & 3.10 & 1.26 & 0.94 \\
3 & 1 & YES & 3.44 & 1.34 & 1.02 \\
4 & 2 & YES & 3.77 & 1.54 & 1.17 \\
5 & 5 & YES & 4.09 & 1.74 & 1.42 \\
6 & 1 & NO & 5.41 & 1.73 & 1.75 \\
7 & 2 & NO & 5.63 & 1.90 & 1.38 \\
\hline
\end{tabular}

MAC values for the photolysis of $3 \mathrm{MC}$ in aqueous $\mathrm{NaNO}_{2}$ solutions (from ca. $0.4 \mathrm{~m}^{2} \cdot \mathrm{g}^{-1}$ at $410 \mathrm{~nm}$ for $0.1 \mathrm{mM} \mathrm{NO}_{2}{ }^{-}$to ca. $4 \mathrm{~m}^{2} \cdot \mathrm{g}^{-1}$ at $350 \mathrm{~nm}$ for $5 \mathrm{mM} \mathrm{NO}_{2}{ }^{-}$, see Table 3) are of the same order of magnitude as reported in the literature [42]. Liu et al. [43] found out that MAC of SOA, especially those produced from aromatic precursors, are much higher for high- $\mathrm{NO}_{\mathrm{x}}$ conditions than for low $\mathrm{NO}_{\mathrm{x}}$. In high- $\mathrm{NO}_{\mathrm{x}}$, SOA from toluene was largely composed of nitroaromatic compounds (e.g., $\mathrm{NC}$, dinitrocatechol, and NP), the total absorbance of which accounted for $60 \%$ and $41 \%$ of the overall 
absorbance in the ranges of 300-400 and 400-500 nm, respectively [44]. Jiang et al. [45] has recently reported on MAC values of SOA from unsaturated heterocyclic organic compounds; for example, for pyrrole SOA from nighttime $\mathrm{NO}_{3}$ oxidation, the value of $(\mathrm{MAC})_{290-700 \mathrm{~nm}}$ was $0.34 \pm 0.07 \mathrm{~m}^{2} \cdot \mathrm{g}^{-1}$. In addition, MAC values of water-soluble organic aerosols from different environments have been reported [42]; MAC of $0.3 \mathrm{~m}^{2} \cdot \mathrm{g}^{-1}$ at $532 \mathrm{~nm}$ was found for water-soluble Humic-like-substances(HULIS) fraction of BB aerosol (BBA) in Amason basin [46] and 0.5-1.5 $\mathrm{m}^{2} \cdot \mathrm{g}^{-1}$ at $404 \mathrm{~nm}$ for ambient BB organic aerosol (BBOA) in Boulder, Colorado [47]. Based on our results, we can conclude that during the reaction of $3 \mathrm{MC}$ and $\mathrm{NaNO}_{2}$, both in the sunlight and in the dark, light-absorbing components are formed, largely $\mathrm{MNC}$, which efficiently absorb light in the range characteristic of $\mathrm{BrC}$. For comparison, in the aqueous reaction of $3 \mathrm{MC}$ at low $\mathrm{NaNO}_{2}$ concentration (experiment 1), for a factor of more than 2 more $\mathrm{BrC}$ is formed (MAC is ca. $1.8 \mathrm{~m}^{2} \cdot \mathrm{g}^{-1}$ at $350 \mathrm{~nm}$ ) than from toluene at high- $\mathrm{NO}_{\mathrm{x}}$ conditions at moderate RH (MAC, $0.8 \mathrm{~m}^{2} \cdot \mathrm{g}^{-1}$ at $365 \mathrm{~nm}$ ) [43].

\section{Conclusions}

This study demonstrates that aqueous-phase transformations of 3MC in the presence of $\mathrm{HNO}_{2} / \mathrm{NO}_{2}{ }^{-}$under atmospheric sunlight conditions importantly contribute to the secondary $\mathrm{BrC}$ formation. The two primary products, 3M5NC and 3M4NC, which have been identified as the main products of nighttime processing and shown to strongly absorb in the near UV range [27], are also formed under the sunlight. However, their cumulative yield is only up to about $45 \%$ under illumination and was additionally found to be dependent on the initial concentration of $\mathrm{NO}_{2}{ }^{-}$. When $\mathrm{NO}_{2}{ }^{-}$is in excess with respect to $3 \mathrm{MC}$, the rate constant of $3 \mathrm{MC}$ degradation $\left(k_{2 n d}(\right.$ global $\left.)=0.075 \mathrm{M}^{-1} \cdot \mathrm{s}^{-1}\right)$ is twice as high as in the dark $\left(k_{2 n d}=0.032 \mathrm{M}^{-1} \cdot \mathrm{s}^{-1}\right)$ under the same initial conditions. Several different degradation mechanisms are possible in the sunlight. Besides the non-radical nitration reaction, which has already been studied in the dark, different reactive species can be formed during the photolysis of $\mathrm{HNO}_{2}$ (e.g., $\mathrm{OH}, \mathrm{NO}, \mathrm{NO}_{2}$ ), which are also possible sinks of $3 \mathrm{MC}$.

The dependence of absorbance evolution on the initial $\mathrm{NO}_{2}{ }^{-} / 3 \mathrm{MC}$ concentration ratio during the photolysis showed that when the ratio is 1 , the absorption around $350 \mathrm{~nm}$ increases with time, which corresponds to the formation of identified first-generation products (3M5NC and 3M4NC). At higher concentration ratios, the absorption at this wavelength substantially increases, and the absorption above $400 \mathrm{~nm}$ becomes pronounced as well. The second-generation products, i.e., $3 \mathrm{M} 5 \mathrm{NC}-\mathrm{OH}$ and the oxidative cleavage products of $3 \mathrm{M} 4 \mathrm{NC}$, were confirmed to be responsible for the absorption in the visible region.

With higher $\mathrm{NO}_{2}{ }^{-}$concentrations, the characteristic MAC values (up to more than $4 \mathrm{~m}^{2} \cdot \mathrm{g}^{-1}$ at $350 \mathrm{~nm}$ for $5 \mathrm{mM} \mathrm{NO}_{2}{ }^{-}$) increase due to more $\mathrm{BrC}$ formation. We believe that the aqueous-phase reaction of 3MC in the presence of $\mathrm{HNO}_{2} / \mathrm{NO}_{2}{ }^{-}$, either under the sunlight or in the dark, may significantly contribute to SOA light absorption. This is supported by the fact that MNC and secondary hydroxylated/ring cleavage products produced from 3MC significantly absorb light in the range characteristic of BrC. Our conclusions are also supported by recent field measurements of aerosol particles, where MNC have been identified as significant contributors to atmospheric $\operatorname{BrC}[15-19,22]$.

Author Contributions: K.V. performed the experiments, conducted the research, and helped to write the manuscript; M.Š. helped in product identification; A.K. contributed to the data analysis and writing process; and I.G. wrote the manuscript. All authors have read and agreed to the published version of the manuscript.

Funding: This research received no external funding.

Acknowledgments: We acknowledge the financial support from the Slovenian Research Agency (research core funding No. P1-0034). We thank Luka Nunar for his help with experimental work.

Conflicts of Interest: The authors declare no competing financial interests. 


\section{References}

1. Laskin, A.; Laskin, J.; Nizkorodov, S.A. Chemistry of Atmospheric Brown Carbon. Chem. Rev. 2015, 115, 4335-4382. [CrossRef]

2. Teich, M.; van Pinxteren, D.; Wang, M.; Kecorius, S.; Wang, Z.B.; Muller, T.; Mocnik, G.; Herrmann, H. Contributions of nitrated aromatic compounds to the light absorption of water-soluble and particulate brown carbon in different atmospheric environments in Germany and China. Atmos. Chem. Phys. 2017, 17, 1653-1672. [CrossRef]

3. Xie, M.J.; Chen, X.; Hays, M.D.; Holder, A.L. Composition and light absorption of N-containing aromatic compounds in organic aerosols from laboratory biomass burning. Atmos. Chem. Phys. 2019, 19, 2899-2915. [CrossRef]

4. Bond, T.C. Spectral dependence of visible light absorption by carbonaceous particles emitted from coal combustion. Geophys. Res. Lett. 2001, 28, 4075-4078. [CrossRef]

5. Feng, Y.; Ramanathan, V.; Kotamarthi, V.R. Brown carbon: A significant atmospheric absorber of solar radiation? Atmos. Chem. Phys. 2013, 13, 8607-8621. [CrossRef]

6. Andreae, M.O.; Gelencser, A. Black carbon or brown carbon? The nature of light-absorbing carbonaceous aerosols. Atmos. Chem. Phys. 2006, 6, 3131-3148. [CrossRef]

7. Saleh, R.; Robinson, E.S.; Tkacik, D.S.; Ahern, A.T.; Liu, S.; Aiken, A.C.; Sullivan, R.C.; Presto, A.A.; Dubey, M.K.; Yokelson, R.J. Brownness of organics in aerosols from biomass burning linked to their black carbon content. Nat. Geosci. 2014, 7, 647-650. [CrossRef]

8. Pflieger, M.; Kroflič, A. Acute toxicity of emerging atmospheric pollutants from wood lignin due to biomass burning. J. Hazard. Mater. 2017, 338, 132-139. [CrossRef]

9. Wang, L.; Wang, X.; Gu, R.; Wang, H.; Yao, L.; Wen, L.; Zhu, F.; Wang, W.; Xue, L.; Yang, L. Observations of fine particulate nitrated phenols in four sites in northern China: concentrations, source apportionment, and secondary formation. Atmos. Chem. Phys. 2018, 18, 4349-4359. [CrossRef]

10. Saleh, R.; Hennigan, C.J.; McMeeking, G.R.; Chuang, W.K.; Robinson, E.S.; Coe, H.; Donahue, N.M.; Robinson, A.L. Absorptivity of brown carbon in fresh and photo-chemically aged biomass-burning emissions. Atmos. Chem. Phys. 2013, 13, 7683-7693. [CrossRef]

11. Kroflič, A.; Grilc, M.; Grgić, I. Unraveling Pathways of Guaiacol Nitration in Atmospheric Waters: Nitrite, A Source of Reactive Nitronium Ion in the Atmosphere. Environ. Sci. Technol. 2015, 49, 9150-9158. [CrossRef]

12. McNeill, V.F. Aqueous Organic Chemistry in the Atmosphere: Sources and Chemical Processing of Organic Aerosols. Environ. Sci. Technol. 2015, 49, 1237-1244. [CrossRef]

13. Harrison, M.A.J.; Barra, S.; Borghesi, D.; Vione, D.; Arsene, C.; Olariu, R.L. Nitrated phenols in the atmosphere: a review. Atmos. Environ. 2005, 39, 231-248. [CrossRef]

14. Hoffmann, E.H.; Tilgner, A.; Wolke, R.; Boge, O.; Walter, A.; Herrmann, H. Oxidation of substituted aromatic hydrocarbons in the tropospheric aqueous phase: Kinetic mechanism development and modelling. Phys. Chem. Chem. Phys. 2018, 20, 10960-10977. [CrossRef]

15. Claeys, M.; Vermeylen, R.; Yasmeen, F.; Gomez-Gonzalez, Y.; Chi, X.G.; Maenhaut, W.; Meszaros, T.; Salma, I. Chemical characterisation of humic-like substances from urban, rural and tropical biomass burning environments using liquid chromatography with UV/vis photodiode array detection and electrospray ionisation mass spectrometry. Environ. Chem. 2012, 9, 273-284. [CrossRef]

16. Kitanovski, Z.; Grgić, I.; Vermeylen, R.; Claeys, M.; Maenhaut, W. Liquid chromatography tandem mass spectrometry method for characterization of monoaromatic nitro-compounds in atmospheric particulate matter. J. Chromatogr. A 2012, 1268, 35-43. [CrossRef]

17. Kahnt, A.; Behrouzi, S.; Vermeylen, R.; Shalamzari, M.S.; Vercauteren, J.; Roekens, E.; Claeys, M.; Maenhaut, W. One-year study of nitro-organic compounds and their relation to wood burning in PM10 aerosol from a rural site in Belgium. Atmos. Environ. 2013, 81, 561-568. [CrossRef]

18. Chow, K.S.; Huang, X.H.H.; Yu, J.Z. Quantification of nitroaromatic compounds in atmospheric fine particulate matter in Hong Kong over 3 years: Field measurement evidence for secondary formation derived from biomass burning emissions. Environ. Chem. 2016, 13, 665-673. [CrossRef]

19. Wang, X.F.; Gu, R.R.; Wang, L.W.; Xu, W.X.; Zhang, Y.T.; Chen, B.; Li, W.J.; Xue, L.K.; Chen, J.M.; Wang, W.X. Emissions of fine particulate nitrated phenols from the burning of five common types of biomass. Environ. Pollut. 2017, 230, 405-412. [CrossRef] 
20. Pereira, K.L.; Hamilton, J.F.; Rickard, A.R.; Bloss, W.J.; Alam, M.S.; Camredon, M.; Ward, M.W.; Wyche, K.P.; Munoz, A.; Vera, T.; et al. Insights into the Formation and Evolution of Individual Compounds in the Particulate Phase during Aromatic Photo-Oxidation. Environ. Sci. Technol. 2015, 49, 13168-13178. [CrossRef]

21. Yuan, B.; Liggio, J.; Wentzell, J.; Li, S.-M.; Stark, H.; Roberts, J.M.; Gilman, J.; Lerner, B.; Warneke, C.; Li, R. Secondary formation of nitrated phenols: Insights from observations during the Uintah Basin Winter Ozone Study (UBWOS) 2014. Atmos. Chem. Phys. 2016, 16, 2139-2153. [CrossRef]

22. Frka, S.; Šala, M.; Kroflič, A.; Huš, M.; Čusak, A.; Grgić, I. Quantum Chemical Calculations Resolved Identification of Methylnitrocatechols in Atmospheric Aerosols. Environ. Sci. Technol. 2016, 50, 5526-5535. [CrossRef] [PubMed]

23. Kroflič, A.; Huš, M.; Grilc, M.; Grgić, I. Underappreciated and Complex Role of Nitrous Acid in Aromatic Nitration under Mild Environmental Conditions: The Case of Activated Methoxyphenols. Environ. Sci. Technol. 2018, 52, 13756-13765. [CrossRef] [PubMed]

24. Lim, Y.B.; Tan, Y.; Perri, M.J.; Seitzinger, S.P.; Turpin, B.J. Aqueous chemistry and its role in secondary organic aerosol (SOA) formation. Atmos. Chem. Phys. 2010, 10, 10521-10539. [CrossRef]

25. Ervens, B.; Turpin, B.J.; Weber, R.J. Secondary organic aerosol formation in cloud droplets and aqueous particles (aqSOA): A review of laboratory, field and model studies. Atmos. Chem. Phys. 2011, 11, 11069-11102. [CrossRef]

26. Iinuma, Y.; Boge, O.; Grafe, R.; Herrmann, H. Methyl-Nitrocatechols: Atmospheric Tracer Compounds for Biomass Burning Secondary Organic Aerosols. Environ. Sci. Technol. 2010, 44, 8453-8459. [CrossRef]

27. Vidović, K.; Jurković, D.L.; Šala, M.; Kroflič, A.; Grgić, I. Nighttime Aqueous-Phase Formation of Nitrocatechols in the Atmospheric Condensed Phase. Environ. Sci. Technol. 2018, 52, 9722-9730. [CrossRef]

28. Vidović, K.; Kroflič, A.; Jovanovič, P.; Šala, M.; Grgić, I. Electrochemistry as a Tool for Studies of Complex Reaction Mechanisms: The Case of the Atmospheric Aqueous-Phase Aging of Catechols. Environ. Sci. Technol. 2019, 53, 11195-11203. [CrossRef]

29. Albinet, A.; Minero, C.; Vione, D. UVA irradiation induces direct phototransformation of 2, 4-dinitrophenol in surface water samples. Chemosphere 2010, 80, 759-763. [CrossRef]

30. Zhao, S.F.; Ma, H.J.; Wang, M.; Cao, C.Q.; Xiong, J.; Xu, Y.S.; Yao, S.D. Study on the mechanism of photo-degradation of p-nitrophenol exposed to $254 \mathrm{~nm}$ UV light. J. Hazard. Mater. 2010, 180, 86-90. [CrossRef]

31. Slade, J.H.; Knopf, D.A. Heterogeneous $\mathrm{OH}$ oxidation of biomass burning organic aerosol surrogate compounds: Assessment of volatilisation products and the role of $\mathrm{OH}$ concentration on the reactive uptake kinetics. Phys. Chem. Chem. Phys. 2013, 15, 5898-5915. [CrossRef] [PubMed]

32. Zhao, R.; Lee, A.K.Y.; Huang, L.; Li, X.; Yang, F.; Abbatt, J.P.D. Photochemical processing of aqueous atmospheric brown carbon. Atmos. Chem. Phys. 2015, 15, 6087-6100. [CrossRef]

33. Hems, R.F.; Abbatt, J.P.D. Aqueous Phase Photo-oxidation of Brown Carbon Nitrophenols: Reaction Kinetics, Mechanism, and Evolution of Light Absorption. ACS Earth Space Chem. 2018, 2, 225-234. [CrossRef]

34. Palumbo, A.; Napolitano, A.; d'Ischia, M. Nitrocatechols versus nitrocatecholamines as novel competitive inhibitors of neuronal nitric oxide synthase: Lack of the aminoethyl side chain determines loss of tetrahydrobiopterin-antagonizing properties. Bioorg. Med. Chem. Lett. 2002, 12, 13-16. [CrossRef]

35. Kitanovski, Z.; Grgić, I.; Yasmeen, F.; Claeys, M.; Čusak, A. Development of a liquid chromatographic method based on ultraviolet-visible and electrospray ionization mass spectrometric detection for the identification of nitrocatechols and related tracers in biomass burning atmospheric organic aerosol. Rapid Commun. Mass Spectrom. 2012, 26, 793-804. [CrossRef]

36. Kitanovski, Z.; Čusak, A.; Grgić, I.; Claeys, M. Chemical characterization of the main products formed through aqueous-phase photonitration of guaiacol. Atmos. Meas. Tech. 2014, 7, 2457-2470. [CrossRef]

37. Vione, D.; Maurino, V.; Minero, C.; Pelizzetti, E. Phenol photonitration upon UV irradiation of nitrite in aqueous solution I: Effects of oxygen and 2-propanol. Chemosphere 2001, 45, 893-902. [CrossRef]

38. He, L.; Schaefer, T.; Otto, T.; Kroflič, A.; Herrmann, H. Kinetic and Theoretical Study of the Atmospheric Aqueous-Phase Reactions of OH Radicals with Methoxyphenolic Compounds. J. Phys. Chem. A 2019, 123, 7828-7838. [CrossRef]

39. Kroflič, A.; Schaefer, T.; Huš, M.; Phuoc Le, H.; Otto, T.; Herrmann, H. OH radicals reactivity towards phenol-related pollutants in water: temperature dependence of the rate constants and novel insights into the [OH-phenol] adduct formation. Phys. Chem. Chem. Phys. 2020, 22, 1324-1332. [CrossRef] 
40. Nakayama, T.; Sato, K.; Matsumi, Y.; Imamura, T.; Yamazaki, A.; Uchiyama, A. Wavelength and $\mathrm{NO}_{\mathrm{x}}$ dependent complex refractive index of SOAs generated from the photooxidation of toluene. Atmos. Chem. Phys. 2013, 13, 531-545. [CrossRef]

41. Li, Y.J.; Huang, D.D.; Cheung, H.Y.; Lee, A.K.Y.; Chan, C.K. Aqueous-phase photochemical oxidation and direct photolysis of vanillin-A model compound of methoxy phenols from biomass burning. Atmos. Chem. Phys. 2014, 14, 2871-2885. [CrossRef]

42. Bluvshtein, N.; Lin, P.; Flores, J.M.; Segev, L.; Mazar, Y.; Tas, E.; Snider, G.; Weagle, C.; Brown, S.S.; Laskin, A.; et al. Broadband optical properties of biomass-burning aerosol and identification of brown carbon chromophores. J. Geophys. Res. Atmos. 2017, 122, 5441-5456. [CrossRef]

43. Liu, J.M.; Lin, P.; Laskin, A.; Laskin, J.; Kathmann, S.M.; Wise, M.; Caylor, R.; Imholt, F.; Selimovic, V.; Shilling, J.E. Optical properties and aging of light-absorbing secondary organic aerosol. Atmos. Chem. Phys. 2016, 16, 12815-12827. [CrossRef]

44. Lin, P.; Liu, J.M.; Shilling, J.E.; Kathmann, S.M.; Laskin, J.; Laskin, A. Molecular characterization of brown carbon $(\mathrm{BrC})$ chromophores in secondary organic aerosol generated from photo-oxidation of toluene. Phys. Chem. Chem. Phys. 2015, 17, 23312-23325. [CrossRef]

45. Jiang, H.H.; Frie, A.L.; Lavi, A.; Chen, J.Y.; Zhang, H.F.; Bahreini, R.; Lin, Y.H. Brown Carbon Formation from Nighttime Chemistry of Unsaturated Heterocyclic Volatile Organic Compounds. Environ. Sci. Technol. Lett. 2019, 6, 184-190. [CrossRef]

46. Hoffer, A.; Gelencser, A.; Guyon, P.; Kiss, G.; Schmid, O.; Frank, G.P.; Artaxo, P.; Andreae, M.O. Optical properties of humic-like substances (HULIS) in biomass-burning aerosols. Atmos. Chem. Phys. 2006, 6, 3563-3570. [CrossRef]

47. Lack, D.A.; Richardson, M.S.; Law, D.; Langridge, J.M.; Cappa, C.D.; McLaughlin, R.J.; Murphy, D.M. Aircraft Instrument for Comprehensive Characterization of Aerosol Optical Properties, Part 2: Black and Brown Carbon Absorption and Absorption Enhancement Measured with Photo Acoustic Spectroscopy. Aerosol Sci. Technol. 2012, 46, 555-568. [CrossRef] 